\title{
Oral health indicators in primary health care: the understanding and the information recorded by dentist-surgeons
}

\author{
Indicadores de saúde bucal da atenção básica: a compreensão e a informação registrada pelos cirurgiões-dentistas
}

Patrícia Maria Costa de OLIVEIRA ${ }^{1}$

Léa Maria Bezerra de MENEZES ${ }^{1}$

Maria Vieira de Lima SAINTRAIN²

Paulo César de ALMEIDA ${ }^{1,2}$

Maria Eneide Leitão de ALMEIDA

\section{ABSTRACT}

Objective

This study aimed to know the understanding of Oral health indicators recommended by the Ministry of Health by dentists in the family health strategy of the state of Ceará in 2008.

\section{Methods}

It is a descriptive, cross-sectional study in which it was used a questionnaire to obtain the data concerning the way information on oral health actions performed in Family Health Care Units and other social spaces are registered, as well as investigate their knowledge about oral health indicators. The calculation of the sample of dentist-surgeons adopted an absolute sampling error of $6.8 \%$ and a significance level of $5 \%$, resulting in an initial sample of 175 dentists; however, only 159 participated in this study according to the inclusion criteria. For instance, they should have been working in the service in the period from 2001 to 2007. In all, 32 cities participated in the research, distributed in 18 Regional Health Cells selected by drawing lots. The data were processed in the program SPSS version 17.0 and considered statistically significant the inferential analyses with $p<0.05$.

\section{Results}

it was observed that there are differences between the interpretation of the indicators objectives and the data relating to oral health actions recorded by dentist-surgeons from the Family Health Strategy. They also differ from the guidelines of the Ministry of Health.

\section{Conclusion}

The pregnant present some knowledge about oral health that can be improved by means of educational, preventive and healing programs. This group exert big it influences in the family ambit, could act as agents multipliers and avoiding the child's precocious contamination.

Indexing terms: Family Health Strategy. Health Status Indicators. Oral health.

\section{RESUMO}

Objetivo

Conhecer o entendimento e informações fornecidas pelos cirurgiões-dentistas atuantes na Estratégia Saúde da Família do Estado do Ceará no ano de 2008 acerca dos indicadores de Saúde Bucal preconizados pelo Ministério da Saúde.

\section{Métodos}

Para isso, utilizou-se um instrumento (questionário) que foi aplicado aos cirurgiões-dentistas atuantes na Estratégia Saúde da Família do Estado, onde se indagou a respeito do conhecimento deles sobre os indicadores de Saúde Bucal e como costumavam informar as ações de Saúde Bucal que realizavam diariamente nas Unidades Básicas de Saúde da Família e nos demais espaços sociais em que atuavam.

\section{Resultados}

Observou-se que há divergências entre a interpretação dos objetivos dos indicadores e o registro dos dados relativos às ações de Saúde Bucal pelos cirurgiões-dentistas atuantes na Estratégia Saúde da Família.

\section{Conclusão}

Há a necessidade de serem implementadas medidas de capacitação permanente para esclarecer aspectos relacionados aos indicadores de Saúde Bucal.

Termos de indexação: Estratégia Saúde da Família. Indicadores básicos de saúde. Saúde bucal.

\footnotetext{
${ }^{1}$ Universidade Federal do Ceará, Faculdade de Farmácia, Odontologia e Enfermagem, Departamento de Clínica Odontológica. Rua Alexandre Baraúna, 949, Rodolfo Teófilo, 60430-160, Fortaleza, CE, Brasil. Correspondência para / Correspondence to: PMC OLIVEIRA. E-mail: <patriciaufc@yahoo.com>. ${ }^{2}$ Universidade de Fortaleza, Diretoria do Centro de Ciências da Saúde. Fortaleza, CE, Brasil.

${ }^{3}$ Universidade Estadual do Ceará, Centro de Ciências da Saúde, Departamento de Saúde Pública. Fortaleza, CE, Brasil.
} 


\section{INTRODUCTION}

Since the creation of a financial incentive provided by the Ministry of Health for the insertion of dentistsurgeons in the Family Health Care teams, in 2001, the population coverage has been increasing fast all over the country.

In this context, the demand of dentistry professionals for their insertion in Family Health Care teams, in addition to the Ministry of Health awareness of the need for strategic and urgent changes in the current dental care framework of the country - represented by a population living at the margins of dental care - and the financial investments offered by the Federal Government for the inclusion of the dentist-surgeon in the Family Health Program require, at this point, an analysis of actions implemented to verify whether they caused significant impact on Oral Health indicators.

According to Pereira et al. ${ }^{1}$, the impacts refer to alterations or effective changes caused by the program itself in the reality in which it operates.

It is important to highlight the fact that the monitoring of these actions should be performed with the aim of improving the users' oral health, including the evaluation of those who are directly responsible for implementing and reporting procedures, enabling then, the creation of a real portrait through reliable information that can direct future work towards the needs presented. The distorted information entails potential errors in the calculation of indicators and consequently impairs the evaluation.

Chaves \& Silva ${ }^{2}$ highlighted the need to investigate how oral health practices are developed and implemented in different organizational and political contexts and the extent to which agents of these practices establish and understand their actions.

This study investigated dentist-surgeons' interpretation of the objectives of the Oral Health indicators of the Primary Care Pact (Pacto de Atenção Primária) and how they are informing about Oral Health actions they perform in the state of Ceará.

The lack of specific literature and originality of this work in regarding the state of Ceará demonstrate its relevance and the possibility to redirect Oral Health policies through an analysis of the results obtained.

\section{METHODS}

This is a descriptive, exploratory cross-sectional study that used an evaluation questionnaire with the dentistsurgeons of the Family Health Program in the state of Ceará.

\section{Validation of the instrument}

The instrument applied to dentist-surgeons was previously validated. The validation counted on three professors from the Collective Oral Health Department, who offered suggestions concerning the formatting of the questionnaire.

The aforementioned professors received a form for analysis in order to verify whether there was correspondence between the questions asked and the objectives relating to each of them. They also assessed the clarity in the drafting of the questions. They should place and " $X$ " on the line corresponding to AGREE or DISAGREE below the question proposed whether or not there was consistency between questions, answer options and objectives. In case the question raised any doubts, the professors marked the line corresponding to DISAGREE, and, if possible, described such doubts in the space provided for comments and suggestions for changes.

\section{Pilot study}

Still in the stage of validation of the instrument, a pilot study was carried out prior to collection in order to check if the evaluation tool or methodology were appropriate. Some changes in the formulation of questions were made in order to dispel potential doubts about the meaning of the questions.

To conduct the pilot study, the proposed questionnaire was administered to fifteen dentist-surgeons from the Regional Health Cell ( ${ }^{\text {a }}$. Célula Regional de Saúde - CRES) of the state of Ceará, who met the trial inclusion criteria, though they did not participate in the sample.

\section{Study sample}

The delimitation of the sample took into account the fact that there are 184 municipalities in Ceará registered in 21 Health Care Microregions, and a total of 1,215 oral health teams deployed by the year 20074 . The $22^{\mathrm{a}}$ CRES, established in 2005, is still technically and administratively subordinated to the CRES of Fortaleza; therefore, it was not considered for the sample calculation.

\section{Sample calculation}

The calculation of the sample of dentist-surgeons was performed using the formula 5 suitable for finite populations. The percentage of professionals' reasonable opinion concerning the indicators was set at $50 \%$, with an absolute sampling error of $6.8 \%$ and a significance level of $5 \%{ }^{3}$. 
Considering the years from 2001 to 2007 and a population of 1,215 dentist-surgeons working in the state of Ceará, the sample comprised 175 dentist-surgeons.

The sample of CRES was stratified in order to calculate the amount of dentist-surgeons and CRES municipalities that would participate in the sample. Then, the draw of the subjects was carried out.

There was a sample loss of circa 10\% that had already been predicted in the initial calculation. The initial sample consisted of 175 dentist-surgeons, but only 159 met the inclusion criteria. There was no impairment of the representativeness of the population.

The sample size calculation considered a $\mathrm{p}$ value set at 20\%, a significance level of 5\% $(\alpha 0.05)$ and an absolute sampling error of $9 \%$. These values, applied in the aforementioned formula that is suitable for finite populations $(n=184)$, provided a sample of size " $n$ " equivalent to 50 municipalities.

In all, 32 municipalities distributed in 18 CRES participated in the research. The sample loss had already been predicted in the initial calculation; hence, it did not impair the representativeness of the population.

\section{Inclusion and exclusion criteria}

Dentist-surgeons who directly performed activities relating to the Family Health Strategy in the period from 2001-2007 were included in the study.

Dentist-surgeons who held Secretary of Health or Manager of Oral Health Administration jobs, such as coordinators and/or supervisors were excluded from the study, as well as those who had worked for less than six months in the Family Health Strategy to the date of the questionnaire application and dentist-surgeons who refused to participate in the study.

\section{Methodology}

A questionnaire was applied to the dentistsurgeons of oral health teams, who were asked about the understanding of the goals of oral health indicators that have been established in the state of Ceará and the way they informed the Oral Health procedures in information maps of the Primary Care outpatient services (Daily Consultation Mapping and Outpatient Production Bulletin).

The research was conducted in partnership with the Center for Oral Health Care of the State Health Secretariat, which provided data on Oral Health concerning the time series assessed, and also facilitated the contact with dentist-surgeons of the municipalities by phone, facsimile and electronic mail.
Initially, for the application of the questionnaire, names of dentist-surgeons belonging to oral health teams of the municipalities of Ceará were searched in the electronic database of the National Registry of Health Facilities (CNES), listing those who worked in the municipalities belonging to the CRES.

The draw of participating municipalities was conducted based on the sample size calculation of municipalities by CRES. Municipalities that formed the CRES were separated into containers according to their corresponding CRES, totaling 21 containers. Each one had small cards with the names of municipalities that comprised the CRES. The draw took place withdrawing the cards with the name of each municipality out of the containers until the number of municipalities expected in the calculation of stratification by CRES was reached.

Then, the dentist-surgeons were drawn. To do so, the names of professionals of the participating municipalities were separated by CRES and drawn until the stratified sample was reached.

The content about each municipality, with the names of the dentist-surgeons drawn, research participant's material, information to managers and return envelope (pre-sealed and addressed to the researcher) were mailed to the Municipal Health Secretariats.

Each municipality drawn was contacted via phone calls made from the Municipal Health Secretariat, in addition to emails and personal phone calls made by the Oral Health coordinators.

Each participant received: a) a copy of the criteria for inclusion and exclusion of dentist-surgeons in the study, b) the free and informed consent form c) evaluation tool (questionnaire).

They were asked to return the material to the researcher within 15 days. If the chosen dentist-surgeon could not answer the questionnaire, managers were instructed to substitute him/her for another one who met the inclusion criteria. If the municipality was not interested or showed difficulties in participating in the research, it would be replaced by another one belonging to the same CRES, which should have a similar number of oral health teams.

\section{Statistical analysis}

Data were organized in tables and graphs. Descriptive statistical analysis of the data was performed using absolute and relative frequencies, in addition to statistical measures:, mean and standard deviation. Variables regarding the dentist-surgeons' knowledge of 
Oral Health indicators of the Primary Care Pact were related to the independent variables: gender, age, working time and training in the Family Health Strategy, through the $x 2$ test (Chi-square) and maximum likelihood estimation.

Inferential analyzes with $p<0.05$ were considered statistically significant. Data were processed in SPSS version 17.0.

\section{Ethical aspects}

The research project was approved by the Research Ethics Committee of the Federal University of Ceará (UFC) under Registration No. 268/07, Official Letter 1147/07, in compliance with the guidelines for research on human beings, according to Resolution No. 196/96 of the Ministry of Health. Dentist-surgeons who agreed to participate in the investigation, after being informed about it, signed the free informed consent form.

\section{RESULTS}

The results of the study showed that $62.3 \%$ (99) of the sample was comprised by female dentist-surgeons, and $51.6 \%$ (82) were aged $23-30$ years at the time of the research - which took place between October 2008 and March 2009.

Regarding working time, $39.6 \%$ (63) of the respondents had worked in the program from three to six years, with an arithmetic mean of 4.4 years.

Concerning the Training Course for working in the Family Health Strategy, 63.5\% (101) of dentist-surgeons said they had participated in courses related to this field.

When asked about the main oral health indicators in the state of Ceará that they know, $48 \%$ of dentists answered at least one word that identified the three indicators established by the Primary Care Pact, but none was able to write the official name of at least one of them.

A percentage of $63.5 \%$ (101) of dentist-surgeons had access to official documentation or manuals informing about the indicators established by the Ministry of Health4.

Although $63.5 \%$ of dentist-surgeons have already taken up a training course in the Family Health Program, only $47.8 \%$ (76) of them considered clear the objectives of the oral health indicators.

When asked about the criteria used to inform the completion of the first dental visit, $52.2 \%$ (83) of dentistsurgeons said that it happens when the patient has his/ her records filled in and he/she is scheduled to return. However, 35.8\% (57) still considered the first dental visit when the patient goes to the dental office for the first time, regardless of other conditions.

When asked about the understanding of the registration of collective procedures performed in the month, a significant variation of answers about this issue emerged. There is still doubt about the information to be registered: whether they should register the number of registered people who participate in collective actions or the amount and frequency of these actions, according to guidelines of the Ministry of Health. In all, 53 (33.3\%) participants say that the registration should consider the number of people enrolled in the Oral Health Prevention Program of the covered area; however, 106 dentistsurgeons still believe that the registration should consider the number of preventive procedures performed or the number of people who benefited from them in that month, regardless of their follow-up and registration in the Prevention program, which is incorrect.

Regarding the indicator concerning the proportion of tooth extractions in relation to basic dental individual actions, only $25.2 \%$ (40) of the participants reported in the code referring to the extraction of permanent elements the extracted teeth that could be restored, while $62.3 \%$ reported in that code, all kinds of extraction, including removal of residual roots, excepting only deciduous teeth.

With regard to the information about the registration of the procedures performed in the daily consultation mapping, 83.6\% (133) answered that they were informed how to do it.

In all, 68.6\% (109) of participants had no doubts about filling out the daily consultation mapping, and $57.2 \%$ (91) reported that the daily consultation mapping is filled out by the dentist-surgeon himself, followed by an Oral Health assistant in $30.8 \%$ (49) of the times.

With regard to the Outpatient Production Bulletin (BPA), $72.3 \%$ (115) of dentist-surgeons received guidance about it, and $61.6 \%$ (98) had no doubt about this procedure.

The results showed that in most of the cases, $67.3 \%$ (107), the dentist was responsible for this achievement.

\section{DISCUSSION}

There was a prevalence of female professionals in oral health teams participating in the sample and a population of young dentist-surgeons. These results are in line with a recent study by Alves et al..$^{5}$ who have verified, 
in Montes Claros, state of Minas Gerais, that the behavior of women's workforce in Dentistry has grown in intensity and constancy.

By the findings of this study, one can notice a significant percentage of professionals already have worked in the Family Health Strategy, who were familiar with the execution of the work of the Oral Health Team supposing, including completing forms relating to the shares held.

Although a percentage higher than half of all professionals had already taken up some training course in the FHP, a large portion has not been trained yet. Considering the fundamental importance of professionals' involvement in implementing the actions proposed by the Family Health Program, it is important that they be properly informed about their role in the consolidation of the Brazilian National Health System (SUS), which is essential to change the exclusionary dental framework of the country that is full of inequities.

Thus, it is important to provide such professionals with continuing education through courses, workshops, debates, and other resources that are essential for the Family Health Strategy. Qualifying all the professionals of the program is undoubtedly a challenge for health care managers, especially because graduation programs, in spite of the proximity with the SUS that has been achieved in recent years, do not approach many peculiar aspects of Collective Oral Health.

The results obtained through the questionnaire concerning the knowledge about the indicators suggests that there is no familiarity with the Oral Health indicators used to monitor the actions performed by these professionals. In this study, respondents reported 12 assessment tools as the main oral health indicators established by the Ministry of Health; for instance, the DMFT, dmft, periodontal indexes, among others. These indexes are recommended by the World Health Organization ${ }^{6}$ to measure and compare the experience of dental caries and periodontal disease in populations; therefore, they are not the main Oral Health indicators recommended by the Ministry of Health. It was observed, in this work, that there is a consistent doubt about the issue that deals with oral health indicators.

The percentage of dentist-surgeons who had access to official documentation or manuals about the indicators established by the Ministry of Health is similar the percentage of professionals who took up a training course. These data suggest that dentist-surgeons only have access to manuals that inform about indicators when they attend the training courses. Possibly, this material is not given by the Municipal Health Secretariats to the professionals working in the Family Health Program, and, sometimes, the professionals are not interested in actively pursuing this official documentation.

Besides the unsatisfactory percentage of professionals who have already taken up a training course in the Family Health Program (63.5\%), the fact that not all professionals are certain about the proposed indicators is excessively alarming. Thus, it is noticed that the oral health indicators are difficult to interpret, and there is a need for further discussion about them with Oral Health workers of the Family Health Strategy.

In addition, the quality of the training courses, the commitment of managers and professionals towards the feasibility, development and participation in the training and, especially, the awareness raising of their importance within the Family Health context, are aspects that could lead to a broader thinking.

According to Araújo \& Dimenstein 7 , many dentistsurgeons believe that the lack of participation in training courses for the Strategy is related to the fact that they consider their participation in the Family Health Program a quick moment, which requires no professional investment. Thus, years go by; the professional remains disqualified in the service because he/she ends up delaying the completion of the training since there is no direct supervision by the manager. Therefore, he/she continues to perform activities with problems that could be solved by the involvement in continuing education.

Training courses should inform dentist-surgeons about the importance of trustworthy record of procedures performed, clarifying questions that could arise from the dentist who is just starting the job, or even the one who is already working in the FHP team. Continuing education is an important ally for highlighting the importance of correct information by recording the actions taken within the Family Health Basic Health Care Units or outside them.

It was observed, in this study, that the dentistsurgeons' idea of the first dental visit is not clear. It is important to emphasize that if professionals registered the first consultation based on such misunderstanding, there is a very different picture of the working reality of these professionals.

According to the Ministry of Health ${ }^{8}$, the first dental visit takes place when a person goes to the dentist in order to start and continue a treatment - not for an emergency or casually.

If, in the times series proposed, the indicator presented data resulting from this wrong concept, the result of the indicator should be even lower than that reported 
consultations that should not be taken into account as the first dental visit.

According to the Ministry of Health, information on the first visit should be recorded by taking the following considerations ${ }^{9}$ : Indicator 29 - First dental consultation coverage. Conceptualization: this indicator measures the trend of coverage of dental treatments from the day of the initial consultation through clinical examination, aiming at developing a treatment plan. It displays, in percentage, the proportion of people who received the first dental consultation prior to restorative dental treatment in primary care in a given place and time. Interpretation: an operational indicator that assesses population's access to oral health services. Usage: enables the analysis of the population provided with the first dental consultation and may indicate trends in the service profile - whether they provide only urgency and emergency services or try to provide an integrated oral health care to the entire population or specific groups.

Until 2006, the indicator of collective procedures, due to the difference between its nomenclature and the interpretation given by the Ministry of Health, considerably hampered its understanding by dentist-surgeons of the Family Health Program. In all, only $33.3 \%$ of dentistsurgeons answered the questionnaire according to the guidelines of the Ministry of Health.

The Ministry of Health makes the following observations on this indicator ${ }^{8}$ : Indicator 30 - ratio between collective dental procedures and the population from 0-14 years old. Conceptualization: this indicator displays, as a ratio, the relationship between Collective Dental Procedures performed and the population from 0-14 years of age (prioritized population). Although the numerator is a procedure code from the SIA / SUS table, this indicator reflects the population of a given place who is benefiting from the oral health promotion and prevention actions. The Collective Dental Procedures code comprises the epidemiological examination, health education, fluoride rinsing and supervised oral hygiene.

The numerator should be calculated by summing up the people assisted every month for a year, dividing the result by 12 (months) to obtain the average annually covered population.

Important notes: special attention should be paid regarding problems in the registration of this procedure. It actually reflects the population covered by preventive actions found in the description of preventive collective procedures in the SIA / SUS table, i.e., the epidemiological examination, health education, fluoride rinsing and supervised oral hygiene.
The municipality must register, in the system, the number of individuals covered (monitored) by collective dental procedures monthly. There should, therefore, be recorded in "number of procedures" performed. Therefore, they should not register the "quantity of procedures" performed.

They must register the population covered during all months of the year, even if actions are held quarterly or at other intervals. Therefore, the indicator refers to an average of people monitored for 12 months. Interpretation: This indicator attempts to check the population's access to oral health prevention actions that make up the Collective Dental Procedures Code, considering a population aged 0-14 years, in a given place for twelve months. Since this indicator is presented as a ratio, the most favorable relationship - indicating a good coverage of oral health preventive actions - would be more distant from 0.0 and close to 1. Usage: to support planning, management and evaluation of oral health policies and actions, and assess the need for expansion of oral health preventive and promotion actions.

Even with the substitution of the indicator "ratio between collective procedures and population aged from zero to fourteen years" for the indicator "Collective Action for Supervised Tooth Brushing" in 2006, what must be informed is the quantity of people who participate in the action/month, regardless of how often they participate. .

Similarly to what has been previously observed for the indicator "first dental consultation" - with regard to the understanding of collective procedures by the dentistsurgeons of the Family Health Program of the State of Ceará - it appears that there was also a wrong record concerning this indicator. Considering the answers given by the professionals, there may have been a record of actions above the reality.

Since there was a stagnation of the indicator in the times series assessed, it should probably present lower values if the misunderstanding was taken into account.

The Ministry of Health makes some observations about the indicator concerning the proportion of tooth extractions in relation to individual basic dental actions ${ }^{8}$ : Indicator 31 - proportion of tooth extractions in relation to individual basic dental actions. Conceptualization: this indicator presents, in percentage, the proportion of extractions of permanent teeth in relation to other individual basic dental actions. Interpretation: this indicator makes it possible to analyze the orientation of the models proposed for individual dental care, as they show the participation of individual mutilating procedures 
(extractions of permanent teeth) in total individual procedures, which should be mostly restorative / conservative and preventive. Usage: to support planning, management and evaluation of oral health policies and actions. To assess the need for expansion of collective preventive actions and individual conservative and prophylactic actions.

If the information recorded in the official production bulletins corresponded to the answer given by dentist-surgeons to the questionnaires used in this study, the number of extractions registered did not match the reality, presenting a considerable increase because they should only record the extractions of permanent teeth that could be restored. Any other types of extraction (removal of residual roots and deciduous teeth) should not have been entered in the code corresponding to the extraction of permanent teeth, avoiding the false reality of superiority of mutilating procedures instead of conservatives ones, allowing for distortions in the evaluation of oral health policies.

If the information provided by the dentist-surgeon were supported by this view, within ideal registration conditions, the indicator would present lower values. This is a positive fact since this indicator tends to decrease.

Regarding the information about the procedures performed filled out in the daily consultation mapping, $83.6 \%$ should be rather close to $100 \%$, since they are basic information needed by all professionals working in the Public Health Care, and which are not addressed in graduation courses.

Of the participants, 68.6\% (109) had no doubts about filling out the daily consultation mapping, indicating that not all professionals who had been informed about it were sufficiently clarified.

There is a chance that professionals do not have an easy access to their immediate supervisor, whom they would possibly run into in case of doubts. The lack of frequent discussions of issues relating to oral health may also have contributed to the result obtained.

Given that the dentist-surgeon is the one who is mostly responsible for filling out the maps, an error can indicate that most mistaken episodes must have been caused by him/her. If they ask any Dentistry assistants to fill out the documents, they must guide them objectively and also raise their awareness of the importance of the trustful record the action performed.

It is clear the need to properly guide the professionals of the Family Health Program. They cannot act without being completely aware of the work they perform. Managers should constantly encourage and seek the training of these professionals, aiming at both the improvement of scientific techniques and the understanding and updating of health care policies guidelines.

It is important to say that many professionals (61.6\%) reported having no doubts about filling out the Outpatient Production Bulletin; however, taking into account the answers given by them, they still filled it incorrectly. The damage is even worse when the error exists, and one is not aware of it. It is suggested that professionals act without the support and guidance of their coordinators I managers and perhaps without a commitment to answer their questions.

Additionally, the findings of Souza \& Roncalli10" should be mentioned for stating that "in several times, municipalities record the information incorrectly"

In this study, it was found that there is inconsistency in the understanding of oral health indicators regarding the guidelines of the Ministry of Health, allowing for incorrect records by professionals.

The report of the 3rd. National Conference on Oral Health states that "health education emphasizes the importance of identifying oral health as a responsibility of local, state and federal governments - especially concerning to the formulation of training policies. It also shows that oral health cannot be separated from people's general health (...)" 11 .

In this context, in order to understand the importance of the accountability of dentist-surgeons of the Family Health Strategy, one should think of Martelli et al. ${ }^{12}$ :

\begin{abstract}
"In the Health Care field, all professionals should be able to develop actions aimed at health promotion, prevention, protection and rehabilitation on an individual and collective level; they should ensure that their work is done continuously and integrated to the other fields in the health care system; they should perform their work within the highest quality standards and meet the principles of bioethics (ethics of life); they should be aware that the responsibility for health care only ends with the resolution of the health problem, both at individual and collective level" (p. 1670).
\end{abstract}

Among many reflections, it is important to highlight the one that considers that the oral health indicators established by the Ministry of Health require greater disclosure and discussion with the workers of the National Health Care System in order to make them more understandable and objective. 
As proposed by Vermelho ${ }^{13}$, the requirements for the development of indices and indicators are: "data availability", "technical simplicity for fast handling and easy understanding ", " uniformity of criteria for benchmarking ", "capacity for synthesis", "discriminatory power, favoring comparisons in time and space".

According Pereira ${ }^{14}$, since the incentive for the implementation of oral health teams in the Family Health Program was established, there has been an exponential growth in the number of teams throughout Brazil. Despite this, little has been done to monitor such inclusion and assess their impacts. This can be observed by the little literature on this topic. In fact, the processes of monitoring and assessing within health care services are often very scarce.

The study results suggest that the training of workers for the National Health Care System is still performed uncritically and without any discussions by the social control, professionals and managers.

The dentist-surgeon must truly take ownership of the Oral Health policies and be engaged in its implementation, hence understanding and applying properly the control and assessment tools used to improve the National Health Care System.

Bueno et al. $^{15}$ point to serious problems in recording information and add that it is necessary to work with the use of indicators developed with the participation of workers from the dental service to be evaluated, in addition to the indicators proposed, by the Ministry of Health and other that traditionally found in the literature.

Lessa \& Vettore $^{16}$ indicate that although the evaluation of policies and programs are included in the agenda of the Ministry of Health, it is observed that the initiatives for evaluating the management oral health in primary care are still embryonic. They show that the

\section{REFERENCES}

1. Pereira CRS, Patrício $A A R$, Araújo FAC, Lucena EES, Lima $K C$, Roncalli AG. Impacto da estratégia saúde da família com equipe de saúde bucal sobre a utilização de serviços odontológicos. Cad Saúde Pública. 2009:25(5):985-96. doi: 10.1590/S0102$311 \times 2009000500005$.

2. Chaves SCL, Silva LMV. As práticas profissionais no campo público de atenção à saúde bucal: o caso de dois municípios da Bahia. Ciênc Saúde Coletiva. 2007;12(6):1697-10. doi: 10.1590/ S1413-81232007000600031.

3. Gil AC. Métodos e técnicas de pesquisa social. $5^{a}$ ed. São Paulo: Atlas; 1999. aggregation of methodologies, exploration of information systems and the use of management documents can contribute to the improvement of this practice.

\section{CONCLUSION}

There are differences between the interpretation of the indicator objectives and the data relating to the Oral Health actions recorded by dentist-surgeons who work in the Family Health Strategy. They also differ from the guidelines of the Ministry of Health.

Oral Health Indicators recommended by the Ministry of Health require greater disclosure and discussion with the workers of the National Health Care System in order to make them more understandable and objective

They should portray the reality of the work process and, from its analysis, direct Oral Health policies.

Continuing education is an important tool that allows for clarification regarding this issue. It is observed that the improvement of indicators is directly related to the understanding of how data should be informed.

\section{Collaborators}

PMC OLIVEIRA performed the collection, analysis and interpretation of data, as well as the literature review and writing of the article. LMB MENEZES conceived and directed the work and helped editing, drafting and writing the article. MVL SAINTRAIN co-supervised the work and contributed in editing, drafting and writing the article. PC ALMEIDA was responsible for statistical analysis and writing of the article. MEL ALMEIDA contributed in the research design and writing of the article.

4. Brasil. Ministério da Saúde. 2007 [homepage da internet] [citado 2008 Ago 10]. Disponível em: <http://www.saude.gov.br>.

5. Alves SFF, Coelho MQ, Costa SM, Martelli DRB, Nascimento JE, Martelli $\mathrm{H}$ Jr, et al. Odontologia no contexto do sistema único de saúde. In: Anais do $3^{\circ}$ Fórum de Ensino, Pesquisa, Extensão e Gestão da Universidade Estadual de Montes Claros; 2009 Set 23-25; Montes Claros. Montes Claros: FEPEG; 2009.

6. World Health Organization: Oral Health Surveys: basic methods $4^{\text {th }}$ edition. Geneva: World Health Organization; 1997.

7. Araujo YP, Dimenstein M. Estrutura e organização do trabalho do cirurgião-dentista no psf de municípios do rio grande do norte. Ciênc Saúde Coletiva. 2006:11(1):219-27. doi: 10.1590/ S1413-81232006000100031 
8. Brasil. Ministério da Saúde. Secretaria de Atenção à Saúde. Departamento de Atenção Básica. Coordenação de Acompanhamento e Avaliação. Avaliação na atenção básica em saúde: caminhos da institucionalização. Brasília: Ministério da Saúde; 2005. [citado 2010 Jul 10]. Disponível em: <http://189.28.128.100/dab/docs/publicacoes/geral/avaliacao_ ab_portugues.pdf>.

9. Brasil. Ministério da Saúde. Secretaria de Atenção à Saúde. Departamento de Atenção Básica. Saúde bucal. Brasília: Ministério da Saúde, 2008 [citado 2010 Jul 10]. Disponível em: <http://bvsms.saude.gov.br/bvs/publicacoes/saude_bucal.pdf>.

10. Souza TMS, Roncalli AG. Saúde bucal no Programa Saúde da Família: uma avaliação do modelo assistencial. Cad Saúde Pública. 2007;23(11):2727-39. doi: 10.1590/S0102$311 \times 2007001100020$

11. Conferência Nacional de Saúde Bucal. Relatório final da $3^{a}$ Conferência Nacional de Saúde Bucal: acesso e qualidade superando a exclusão social. Brasília: Ministério da Saúde; 2004.

12. Martelli PJL, Cabral APS, Pimentel FC, Macedo CLSV, Monteiro IS, Silva SF. Análise do modelo de atenção à saúde bucal em municípios do estado de Pernambuco. Ciênc Saúde Coletiva. 2008;13(5):1669-74. doi: 10.1590/S141381232008000500030 .

13. Vermelho LL, Leal AJC, Kale PL. Indicadores de saúde. In: Medronho RA. Epidemiologia. Rio de Janeiro: Atheneu; 2002. p. 33-56.
14. Pereira DQ, Pereira JCM, Assis MMA. A prática odontológica em Unidades Básicas de Saúde em Feira de Santana (BA) no processo de municipalização da saúde: individual, curativa, autônoma e tecnicista. Ciênc Saúde Coletiva. 2003;8(2):599609. doi: 10.1590/S1413-81232003000200020.

15. Bueno VLRC, Cordoni Junior $L$, Mesas AE. Desenvolvimento de indicadores para avaliação de serviço público de odontologia. Ciênc Saúde Coletiva. 2011;16(7):3069-82. doi: 10.1590/ S1413-81232011000800007.

16. Lessa CFM, Vettore MV. Gestão da atenção básica em saúde bucal no Município de Fortaleza, Ceará, entre 1999 e 2006. Saúde Soc. 2010;19(3):547-56.
Received on: 16/3/2012

Final version resubmitted on: 9/1/2013

Approved on: 28/3/2013 
